\title{
Induction of Ovulation by HCG Injection in the Tropical Walking Catfish Clarias batrachus Reared under $23-25^{\circ} \mathrm{C}$
}

\author{
Muhammad Zairin Jr., ${ }^{* 1}$ Kiyoshi Furukawa, ${ }^{* 1}$ and Katsumi Aida ${ }^{* 1}$ \\ (Received March 7, 1992)
}

\begin{abstract}
A series of trials on induced ovulation were conducted using female walking catfish to examine conditions of maturity under warm water conditions. For this purpose, females were maintained at $23-25^{\circ} \mathrm{C}$ for a long period, either under $12 \mathrm{~L} 12 \mathrm{D}$ or natural photoperiod. Using $12-37$ month-old females, induction of ovulation was achieved with a single injection of HCG $(0.2,0.4,0.8,1.6$, or or $3.2 \mathrm{IU} / \mathrm{g} \mathrm{BW}$ ). In all the trials, HCG treatment succeeded in inducing ovulation at dosages of $0.4 \mathrm{IU} / \mathrm{g}$ BW or higher. Oocytes larger than $770 \mu \mathrm{m}$ responded to HCG and ovulated. Thesc results indicate that female walking catish can maintain conditions of maturity for an extended time under warm water conditions, and can respond to HCG irrespective of photoperiod.
\end{abstract}

The tropical walking catfish Clarias batrachus is a freshwater teleost widely cultured in Southeast Asian countries. This species possesses an interesting feature in its reproductive cycles, which appears to be influenced by the amplitude of local temperature which they inhabit. ${ }^{1)}$ In India, where annual temperature variation is large, this species is an annual spawner, as revealed through observation of oocyte development ${ }^{2)}$ and elucidation of annual profiles of plasma sex steroids. $^{3)}$ On the other hand, in more tropical countries such as Indonesia and Thailand, where temperature is generally warm and annual fluctuations are minimal, the spawning season coincides with the rainy season.*) The final stimulus for natural spawning seems to be associated with a rise in water level and an inundation of marginal area, either as a result of direct rainfall or inflow of water from upstream sources as has been reported in the African catfish. ${ }^{5)}$ Under cultured conditions, spawning in the walking catfish can be induced by the manipulation of water levels. ${ }^{8,73, * 2}$ Recent reports ${ }^{1,87}$ show that the ovulation of this species can be induced during non-spawning season not only by environmental manipulation, but also by hormonal stimulation such as the injection of carp pituitary homogenate or human chorionic gonadotropin (HCG).

These results suggest that the walking catfish can maintain mature conditions throughout the year under tropical conditions and can respond to spawning stimuli at any time. In order to confirm this hypothesis, a series of induced ovulation trials were conducted using catfish maintained under warm temperature for an extended period.

\section{Materials and Methods}

\section{Fish Stock}

1. Grop I: Walking catfish fingerlings were originally obtained from The Faculty of Fisheries, Bogor Agricultural University, Bogor, Indonesia in 1988. These fish were approximately 2 months in age and $3 \mathrm{~cm}$ in total length. Fish were reared for 2 months at a density of 25 fish per aquarium in $80 \mathrm{l}$-aquaria provided with a bottom gravel filter. During this rearing period fish were maintained under natural photoperiod at $27^{\circ} \mathrm{C}$ until reaching about $50 \mathrm{~g}$ in body weight (BW) and $10 \mathrm{~cm}$ in total length.

Thereafter, fish were transferred to the Fisheries Laboratory of The University of Tokyo at Maisaka, Shizuoka Prefecture, due to increased growth and space requirements. Fish were reared in indoor concrete ponds (dimensions: length $\times$ width $\times$ depth $=3 \times 1.5 \times 0.7 \mathrm{~m}$ ) supplied with running freshwater of deep-well origin.

*1 Department of Fisheries, Faculty of Agriculture, The University of Tokyo, Yayoi, Bunkyo, Tokyo 113, Japan (ムハマド ザィリン, 古川 洼, 全时勝美: 東京大学農学部)。

*: Muhammad Zairin, Jr. 1990. Physiological studies on maturation and spawning of channel catfish (Ictalurus punctatus) and walking catfish (Clarias barrachus). Master Thesis. Faculty of Agriculture, The University of Tokyo. $39 \mathrm{p}$. 
During this period, fish were subjected to $12 \mathrm{~L} 12 \mathrm{D}$ photoperiod (Group Ia) or natural photoperiod (Group Ib). Being of deep-well origin, water temperature was nearly constant $\left(23-25^{\circ} \mathrm{C}\right)$ throughout the year. Up to an age of one year, fish were fed twice daily with commercially available trout dry pellets (Chubu Shiryo, Co.) at a ration of $2-3 \%$ of $\mathrm{BW}$. One- to 2-year-old fish were fed once daily at about $1.5 \%$ of BW. Fish above 2 years old were fed every two days at $1.5 \% \mathrm{BW}$, but feeding was intensified to once daily 2 weeks prior to the start of the experiments.

2. Group II: Second generation fish (of those transported from Indonesia in 1988) were also used as experimental material. One month after hatching, fingerlings (Group 1 offsprings) were transferred to indoor concrete ponds $(3 \times$ $1.5 \times 0.4 \mathrm{~m}$ ) supplied with running freshwater of deep-well origin $\left(23-25^{\circ} \mathrm{C}\right)$, and reared under 12L12D (Group IIa) or natural photoperiod (Group IIb). Other rearing conditions were the same as those of Group I.

3. Group III: Fish used in this experiment were also directly transported from Bogor, Indonesia, in 1990 at an age of about 2 months old. After arrival, fish were reared in an outdoor concrete pond $(3 \times 1.5 \times 0.4 \mathrm{~m})$ under natural photoperiod at $23-25^{\circ} \mathrm{C}$ until reaching an age of 8 months.

Table 1. Results of induced ovulation by HCG injection in walking catfish maintained under $23-25^{\circ} \mathrm{C}$

\begin{tabular}{|c|c|c|c|c|c|c|}
\hline \multirow{2}{*}{ Group } & \multirow{2}{*}{$\begin{array}{r}\text { Fish age } \\
\text { (months) }\end{array}$} & \multirow{2}{*}{$\begin{array}{l}\text { HCG dose } \\
\text { (IU/g BW) }\end{array}$} & \multicolumn{2}{|c|}{ Number of fish } & \multirow{2}{*}{$\begin{array}{l}\text { Body weight } \\
\text { (g) }\end{array}$} & \multirow{2}{*}{$\begin{array}{c}\text { Date of } \\
\text { trial }\end{array}$} \\
\hline & & & Used & Ovulated & & \\
\hline \multirow[t]{4}{*}{ Ia } & 13 & 0.6 & 3 & 3 & $450-475$ & Aug., 1989 \\
\hline & 17 & 0.8 & 14 & 14 & $325-675$ & Nov., 1989 \\
\hline & & Control & 10 & 0 & $325-675$ & \\
\hline & 22 & 0.8 & 5 & 5 & $500-800$ & Mar., 1990 \\
\hline \multirow[t]{4}{*}{$\mathrm{Ib}$} & 31 & 0.8 & 10 & 10 & $525-1125$ & Feb., 1991 \\
\hline & & Control & 5 & 0 & $550-875$ & \\
\hline & 37 & 0.8 & 10 & 10 & $600-1200$ & Aug., 1991 \\
\hline & & Control & 5 & 0 & $650-1250$ & \\
\hline \multirow[t]{17}{*}{ IIa } & 13 & 0.8 & 6 & 6 & $300-400$ & Apr., 1990 \\
\hline & 18 & 0.8 & 4 & 4 & $350-500$ & Aug., 1990 \\
\hline & 21 & 0.8 & 5 & 5 & $450-500$ & Nov., 1990 \\
\hline & & 0.7 & 3 & 3 & $400-450$ & \\
\hline & & Control & 3 & 0 & $375-425$ & \\
\hline & 24 & 1.6 & 10 & 10 & $475-775$ & Mar., 1991 \\
\hline & & 0.8 & 10 & 10 & $500-650$ & \\
\hline & & 0.4 & 10 & 10 & $400-775$ & \\
\hline & & 0.2 & 10 & 0 & $425-750$ & \\
\hline & & Control & 10 & 0 & $400-725$ & \\
\hline & 25 & 1.6 & 3 & 3 & $525-550$ & Apr., 1991 \\
\hline & & 0.8 & 3 & 3 & $350-575$ & \\
\hline & & 0.4 & 3 & 3 & $375-650$ & \\
\hline & & 0.2 & 3 & 0 & $400-550$ & \\
\hline & & Control & 3 & 0 & $400-725$ & \\
\hline & 29 & 0.8 & 19 & 19 & $325-475$ & Aug., 1991 \\
\hline & & Control & 9 & 0 & $375-525$ & \\
\hline \multirow[t]{8}{*}{$\mathrm{IIb}$} & 12 & 0.8 & 10 & 10 & $275-325$ & Aug., 1991 \\
\hline & & Control & 5 & 0 & $225-350$ & \\
\hline & 13 & 3.2 & 8 & 8 & $275-325$ & Sep., 1991 \\
\hline & & 1.6 & 8 & 8 & $300-375$ & \\
\hline & & 0.8 & 8 & 8 & $325-375$ & \\
\hline & & 0.4 & 8 & 8 & $275-325$ & \\
\hline & & 0.2 & 8 & 0 & $250-350$ & \\
\hline & & Control & 8 & 0 & $300-425$ & \\
\hline \multirow[t]{2}{*}{ III } & 15 & 0.8 & 13 & 13 & $275-500$ & Aug., 1991 \\
\hline & & Control & 4 & 0 & $275-325$ & \\
\hline
\end{tabular}


Thereafter, they were reared in a slightly larger concrete pond $(3 \times 1.5 \times 0.7 \mathrm{~m})$ under the same conditions. Other rearing conditions were the same as those of Group I.

\section{Induced Ovulation}

Female walking catfish at various ages (1237 months old) were selected from the stock ponds, and given a single muscular injection of HCG (0.2-3.2 IU/g BW, see Table 1) just below the beginning of the dorsal fin, after anesthetizing fish with $600 \mathrm{ppm}$ 2-phenoxyethanol (Wako, Japan). In order to meet the required dose, the original hormone was diluted with $0.6 \% \mathrm{NaCl}$ solution. After injection, fish were maintained in indoor concrete ponds or outdoor containers supplied with running freshwater $\left(23-25^{\circ} \mathrm{C}\right)$, either under $12 \mathrm{~L} 12 \mathrm{D}$ or natural photoperiod. Fish did not receive feed during the experiment. Ovulation was checked at 20,24 , and $30 \mathrm{~h}$ after the HCG injection by applying gentle pressure on the fish's belly.

\section{Measurement of Oocyte Diameter}

In the trial using 25-month-old fish in Group IIa, ovulated eggs were stripped, and all fish were dissected. Small pieces of ovarian tissue were fixed overnight with Bouin's fixative, and then preserved in $70 \%$ alcohol. Measurement of oocyte diameter (about 200 oocytes/fish) were carried out under conditions of preservation in $70 \%$ alcohol.

\section{Results}

\section{Induced Ovulation}

Results of induced ovulation following $\mathrm{HCG}$ injection are summarized in Table 1.

Fish in Group IIa and IIa were reared under 12L12D photoperiod. Fish age ranged from 13 to 29 months old, and trials covered all seasons. In these trials, HCG injection at dosages of 0.4 $1 \mathrm{U} / \mathrm{g} \mathrm{BW}$ or higher succeeded in inducing ovulation in all the treated fish. This indicates that ovulation can be induced at any time in fish reared under $12 \mathrm{~L} 12 \mathrm{D}$ at $23-25^{\circ} \mathrm{C}$. Ovulation was observed $20-30 \mathrm{~h}$ after the $\mathrm{HCG}$ injection of $0.4 \mathrm{IU} / \mathrm{g} \mathrm{BW}$, and $20-24 \mathrm{~h}$ after the injection of higher doses.

Fish in Group Ib, IIb, and III were reared under natural photoperiod. Fish age ranged from 12 to 37 months old. Trials were conducted in winter and summer. Again, all fish treated with $\mathrm{HCG}$ at dosages of $0.4 \mathrm{IU} / \mathrm{g}$ BW or higher ovulated. This indicates that ovulation can be induced either in winter or summer in fish reared under natural photoperiod at $23-25^{\circ} \mathrm{C}$. Ovulation was observed $20-30 \mathrm{~h}$ after the $\mathrm{HCG}$ injection of 0.4 IU/g BW, and 20-24 h after injections of higher doses.

\section{Critical Size of Oocytes for Ovulation}

In order to determine the critical size of mature oocytes which can respond to gonadotropin, various doses of HCG were injected using 25month-old females in Group IIa. The results of this experiment are shown in Table 2. This table shows clear changes in size composition of oocytes after HCG injection. Oocyte size composition in the control group indicated that mature females have a wide size range of vitellogenic oocytes. A single injection of $0.2 \mathrm{IU}$ $\mathrm{HCG} / \mathrm{g}$ BW lowered the percentage of oocytes ranging from 770 to $880 \mu \mathrm{m}$ in diameter, and

Table 2. Changes in size composition of ovarian oocytes following HCG treatment in walking catfish

\begin{tabular}{|c|c|c|c|c|c|}
\hline \multirow{2}{*}{$\begin{array}{l}\text { Oocyte diameter } \\
\qquad(\mu \mathrm{m})\end{array}$} & \multicolumn{5}{|c|}{ Size composition of ovarian oocytes $(\%)^{*}$} \\
\hline & Control & $0.2 \mathrm{IUW} \mathrm{HCG} / \mathrm{g}$ & $0.4 \underset{\mathrm{BW}}{\mathrm{HCCG} / \mathrm{g}}$ & $\begin{array}{c}0.81 \mathrm{UWCG} / \mathrm{g} \\
\mathrm{BW}\end{array}$ & $\underbrace{1.6 \mathrm{IUCG} / \mathrm{g}}_{\mathrm{BW}}$ \\
\hline $110-220$ & $16.4 \pm 3.8$ & $17.0 \pm 12.0$ & $20.0 \pm 6.1$ & $14.6 \pm 1.7$ & $23.9 \pm 2.5$ \\
\hline $220-330$ & $21.3 \pm 3.7$ & $24.8 \pm 5.4$ & $29.3 \pm 1.8$ & $36.0 \pm 5.5$ & $35.4 \pm 2.1$ \\
\hline $330-440$ & $9.5 \pm 0.4$ & $11.0 \pm 2.6$ & $14.1 \pm 3.6$ & $20.1 \pm 0.4$ & $14.8 \pm 2.3$ \\
\hline $440-550$ & $7.0 \pm 1.8$ & $7.3 \pm 0.8$ & $7.5 \pm 0.8$ & $7.8 \pm 0.4$ & $8.4 \pm 0.6$ \\
\hline $550-660$ & $4.7 \pm 0.7$ & $4.7 \pm 1.5$ & $4.4 \pm 0.8$ & $5.2 \pm 1.0$ & $5.6 \pm 0.4$ \\
\hline $660-770$ & $6.4 \pm 1.7$ & $4.7 \pm 0.4$ & $5.4 \pm 0.7$ & $7.1 \pm 1.8$ & $5.5 \pm 0.4$ \\
\hline $770-880$ & $17.4 \pm 2.6$ & $7.7 \pm 0.8$ & $5.9 \pm 0.8$ & $6.3 \pm 0.5$ & $4.8 \pm 0.6$ \\
\hline $880-990$ & $14.7 \pm 3.9$ & $18.6 \pm 3.9$ & $8.5 \pm 3.0$ & $1.4 \pm 0.8$ & $1.3 \pm 0.5$ \\
\hline $990-1100$ & $2.6 \pm 1.1$ & $4.3 \pm 1.4$ & $4.9 \pm 4.4$ & 0 & $0.2 \pm 0.1$ \\
\hline
\end{tabular}

* Expressed as Mean \pm SEM 
increased the percentage of those in the $880-990$ $\mu \mathrm{m}$ and $990-1100 \mu \mathrm{m}$ classes. However, this dosage level is not great enough to induce ovulation, since no fish ovulated at this dose. With a dosage increase to $0.4 \mathrm{IU} / \mathrm{g} \mathrm{BW}$, a small amount of oocytes ovulated, the percentage of oocytes ranging from 770 to $990 \mu \mathrm{m}$ decreased, and the percentage of oocytes ranging from 990 to 1100 $\mu \mathrm{m}$ increased. At a dosage of $0.8 \mathrm{IU} \mathrm{HCG} / \mathrm{g}$ $\mathrm{BW}$, the percentage of oocytes larger than $770 \mu \mathrm{m}$ decreased sharply due to ovulation. At a dosage of $1.6 \mathrm{IU} \mathrm{HCG} / \mathrm{g} \mathrm{BW}$, the pattern of changes in oocyte size composition was similar to that of $0.8 \mathrm{IU} / \mathrm{g} \mathrm{BW}$ treatment, but more oocytes were ovulated.

\section{Discussion}

In this investigation, we have succeeded in inducing ovulation by injecting HCG in female walking catfish which were maintained at 23$25^{\circ} \mathrm{C}$ under $12 \mathrm{~L} 12 \mathrm{D}$ or natural photoperiod for an extended period. These results indicate that fish used in this investigation possessed mature oocytes which were capable of responding to $\mathrm{HCG}$. Since ovulation was induced in fish maintained under both 12L12D and natural photoperiod, photoperiod does not seem to influence gonadal maturation in this species; rather, water temperature is probably a major factor in maintaining conditions of maturity. Endocrine requirements for the maintenance of maturity under constant warm water conditions are under investigation, and will be reported separately.

In other investigations, under either 12L12D or natural photoperiod condition, walking catfish began to mature at an age of 9 months.* However, spontaneous spawning did not occur in the stock ponds, indicating that environmental or hormonal stimuli are necessary for the induction of ovulation, In fact, manipulation of water level ${ }^{8,7)}$ or hormonal treatment such as injection of carp pituitary homogenate or $\mathrm{HCG}^{1,8)}$ are known to be effective in inducing ovulation. The present studies also indicate that HCG is effective in inducing ovulation. All fish treated with HCG at dosages of $0.4 \mathrm{IU} / \mathrm{g}$ BW or higher ovulated $20-30 \mathrm{~h}$ after the treatment. None of fish in the control and $0.2 \mathrm{IU} / \mathrm{g} \mathrm{BW}$ groups ovulated. At $0.4 \mathrm{IU} \mathrm{HCG} / \mathrm{g} \mathrm{BW}$, the quantity of ovulated eggs was small and practically negligible, whereas a large number of ovulated eggs were observed in the groups treated with 0.8 and $1.6 \mathrm{IU} \mathrm{HCG/g}$ BW. These results indicate that these fish possessed oocytes which had already completed vitellogenesis, and that the number of ovulated eggs is dose-dependent. Zonneveld et al. ${ }^{8)}$ recommended the dose of $3 \mathrm{IU} \mathrm{HCG} / \mathrm{g}$ BW for inducing ovulation in this species. In Clarias gariepinus and C. macrocephalus, similar doses were recommended. ${ }^{\theta, 103}$

Regarding oocyte size composition in the control group, individuals in this group exhibited a wide size range of vitellogenic oocytes. Injection of $0.2 \mathrm{IU} \mathrm{HCG} / \mathrm{g}$ BW decreased the percentage of oocytes in the $770-880 \mu \mathrm{m}$ class, and increased the percentage of $880-990 \mu \mathrm{m}$ class oocytes. However, this dose was not sufficient to induce ovulation, since no fish ovulated at this dose. With the dosage increased to $0.4 \mathrm{IU} / \mathrm{g}$ BW, a small amount of oocytes in the 990-1100 $\mu \mathrm{m}$ class ovulated, and the number of oocytes in the $770-880$ and $880-990 \mu \mathrm{m}$ classes decreased (entering into the next class). In fish treated with $0.8 \mathrm{IU} \mathrm{HCG} / \mathrm{g} \mathrm{BW}$, the percentage of oocytes larger than $770 \mu \mathrm{m}$ decreased sharply due to ovulation. In fish treated with $1.6 \mathrm{IU}$ $\mathrm{HCG} / \mathrm{g} \mathrm{BW}$, the pattern of the changes in oocyte size composition was similar to that of the 0.8 IU/g BW treated group, but more oocytes were seen to have ovulated. These results indicate that oocytes larger than $770 \mu \mathrm{m}$ in diameter are responsive to HCG injection and undergo final oocyte maturation and ovulation.

\section{Acknowledgements}

We express our thanks to our colleagues at the Faculty of Fisheries, Bogor Agricultural University, Indonesia, for their kind help in supplying catfish fry stock. We thank $M$. N. Wilder for correcting the English. This study was partially funded by a Grant-in Aid for Scientific Research from the Ministry of Education, Science, and Culture.

\section{References}

1) N. Zonneveld, Rustidja, W. J.A. R. Viveen, and W. Mudana: Induced spawning and egg incubation of the Asian catfish, Clarias batrachus. Aquaculture, 75, 41-47 (1988).

* Muhammad Zairin, Jr. 1990. Physiological studies on maturation and spawning of channel catfish (Ictalurus punctatus) and walking catfish (Clarias batracthus). Master Thesis. Faculty of Agriculturc, The University of Tokyo. 39 p. 
2) G. K. Lehri: Cyclical changes in the ovary of the catfish Clarias batrachus (L.). Acta Anat, 69, 105-124 (1968).

3) S. Singh and T. P. Singh: Seasonal profiles of sex steroids in blood plasma and ovarian tissue of Clarias batrachus. Gen. Comp. Endocrinol., 65, 216-224 (1987).

4) A. Sidthimunka, J. Sanglert, and $O$. Pawapootanon: The Culture of catfish (Clarias spp.) in Thailand, in "FAO Fisheries Reports, 44(5)" (ed. by T. V. R. Pillay), 1968, pp. 196-204 (1968).

5) M. N. Bruton: The breeding biology and early development of Clarias gariepinus (Pisces: Clariidae) in Lake Sibaya, South Africa, with a review of breeding in species of the subgenus Clarias (Clarias), Trans. Zool. Soc. Lond., 35 , 1-45 (1979).

6) W. Tarnchalanukit: Induced spawning of walking catfish, Clarias batrachus, by water level regulation, in "Proc. of the Third Int. Symp. on Reprod. Physiol. of Fish" (ed. by D. R. Idler), St. John's, New Foundland Canada, 1987, p. 138.

7) C. F. Knud-Hansen, T, R. Batterson, C. D. McNabb, Y, Hadiroseyani, D. Dana, and M. Eidman: Hatchery techniques for egg and fry production of Clarias batrachus (Linnaeus). Aquaculture, 89, 9-19 (1990).

8) N. Zonneveld, A. C. Wilbrink, A. Soeprijanto, W. J. A. R. Viveen, and $Y$. Nursalam: Induced spawning of the Asian catfish-Clarias hatrachus-by means of HCG. The Second Asian Fisheries Forum, Tokyo, 1989, pp 587-590.

9) E. H. Eding, J. A. L. Janssen, G. H. J. Klein Staarman, and C. J. J. Richter: Effects of human chorionic gonadotropin (HCG) on maturation and ovalation of oocytes in catfishClarias lazera (C \& V), in "Proc. Int. Symp. Reprod. Physiol. Fish. PUDOC Wageningen", the Netherlands. 1982, p. 185.

10) M. F. A. Mollah and E. S. P. Tan: HCG induced spawning of the catfish-Clarias macrocephalus (Gunther). Aquaculture, 35, 239-245 (1983). 